\title{
Studies on $\mathrm{TiO}_{2} /$ Reduced Graphene Oxide Composites as Cathode Materials for Magnesium-Ion Battery
}

\author{
E. Sheha \\ Physics Department, Faculty of Science, Benha University, Benha, Egypt \\ Email: islam.shihah@fsc.bu.edu.eg, e sheha@yahoo.com
}

Received 17 April 2014; revised 13 May 2014; accepted 18 June 2014

Copyright (C) 2014 by author and Scientific Research Publishing Inc. This work is licensed under the Creative Commons Attribution International License (CC BY). http://creativecommons.org/licenses/by/4.0/ c) (i) Open Access

\section{Abstract}

The aim of this work is to introduce a high performance cathode for magnesium-ion batteries. $\mathrm{TiO}_{2}$ /reduced graphene oxide (rGO) composites were mixed in ball mill. The samples are characterized using XRD and SEM. The spex-milled composites exhibit better electrochemical performance with higher reversible capacity and excellent cyclability. The excellent electrochemical performance of $\mathrm{TiO}_{2} / \mathrm{rGO}$ composites is due to their unique structures, which intimately combine the conductive graphene nanosheets network with $\mathrm{TiO}_{2}$ nanoparticles and possess the characteristic parallel channels running along the [010] orientation, which allow easy $\mathrm{Mg}^{2+}$ transport. It was found that layered $\mathrm{TiO}_{2}$ and $\mathrm{rGO}$ nanosheets in the composite interlace with each other to form novel sandwich-structured microspheres, which exhibit preferable electrochemical performance in rechargeable $\mathrm{Mg}$ batteries.

\section{Keywords}

Graphene, Magnesium Battery, Titanium Dioxide, Cathode

\section{Introduction}

The lithium (Li) battery used as a power source because of its high specific power and high energy density. However, high demand for Li battery tends to make increase in Li price due to geographically limitedness in the earth crust [1]. As an alternative to lithium, magnesium has been foregrounded. Magnesium batteries have recently attracted great interest due to their high energy density and environmentally friendly components, coupled with magnesium's low cost ( $\$ 2700 /$ ton for Mg compared to $\$ 64,000 /$ ton for $\mathrm{Li}$ ) and abundance in the earth’s crust ( 13.9\% Mg compared to $\sim 0.0007 \%$ of Li) [1]-[4]. 
The major obstacles that prohibit Mg batteries from practices are 1) the kinetically sluggish Mg intercalation and diffusion in cathode materials; 2) the incompatibility between anode and electrolyte due to the high polarizing ability of the $\mathrm{Mg}^{2+}$ cation. Therefore, the search for suitable cathode and less passivated anode/electrolyte configuration is intrinsically urging [5]-[8].

Nanostructured $\mathrm{TiO}_{2}$, an abundant, low cost, and environmentally benign material, is structurally stable during Li-ion insertion/extraction, which makes $\mathrm{TiO}_{2}$ particularly attractive for using as anode materials in rechargeable batteries. It possesses the characteristic parallel channels running along the [010] orientation, which allow easy $\mathrm{Li}^{+}$transport and fast charging of the $\mathrm{TiO}_{2}$. In this regard, one-dimensional (1D) $\mathrm{TiO}_{2}$ nanostructure facilitates the electron transport along the long dimension and the two short dimensions ensure fast $\mathrm{Li}^{+}$insertion/ extraction [9]-[11]. $\mathrm{TiO}_{2}$ advantages suffer from its poor electronic conductivity, and thus here are many challenges when employed in the rechargeable batteries.

Graphene, the name given to a flat monolayer of carbon atoms tightly packed into a two-dimensional (2D) honeycomb lattice, exhibits many unusual and intriguing properties in magnetic, electronic and photonic fields. In particular, its superior electrical conductivities, high surface areas and chemical tolerance intrigue great interest in energy storage technologies [9] [12]. To date, a large number of works on $\mathrm{Li}^{\mathrm{T}} \mathrm{TiO} \mathrm{O}_{2}$ have been done, while $\mathrm{TiO}_{2}$ was not investigated as $\mathrm{Mg}^{+2}$ intercalation host for room temperature $\mathrm{Mg}^{+2}$-ion batteries.

Based on the above considerations, in this article, it was demonstrated a simple green route synthesis of novel $\mathrm{TiO}_{2}$ loaded by rGO. The composite was characterized by using XRD, SEM and impedance spectroscopy. Also a reaction mechanism based on the electrochemical measurements and characterization will be suggested. Solid-state $\mathrm{Mg} / \mathrm{PE} /$ (0.6 $\left._{\mathrm{TiO}} \mathrm{T}_{0.4} \mathrm{rGO}\right)$ cell is assembled, and its cycling performances will be briefly examined to evaluate the applicability of on solid-state magnesium batteries.

\section{Experimental}

rGO (Electrical conductivity $>600 \mathrm{~S} / \mathrm{m}$, surface area $\sim 457.18 \mathrm{~m}^{2} / \mathrm{g}$ ) synthesized Via the reduction of Graphene Oxide have been imported from Graphenea company.

Composites of pure $\mathrm{TiO}_{2}$ anatase nanoparticles and rGO were mixed in ball mill for very short time duration. The resulted product is denoted here as ${ }_{0.6} \mathrm{TiO}_{2} /{ }_{0.4} \mathrm{rGO}$ composites.

The electrolyte was prepared by reacting $0.1 \mathrm{gm}$ of Poly (vinyl alcohol), PVA (degree of hydrolization $\geq 98 \%$, $\mathrm{Mw}=72,000)$, $1 \mathrm{gm}$ magnesium bromide $\mathrm{MgBr}_{2}$ and $1 \mathrm{ml}$ tetraethylene glycol dimethyl ether in distilled water.

The morphology of the polymer electrolyte was carried out using SEM (JOEL-JSM Model 5600).

The XRD patterns of the films were taken using Rigaku diffractometer type RINT-Ultima IV/S, Cu $\mathrm{K}_{\alpha}$, voltage $40 \mathrm{kV}$ and $40 \mathrm{~mA}$.

Conductivity measurements were made for $\mathrm{TiO}_{2} / \mathrm{rGO}$ composites by impedance method. Samples of diameter $1.3 \mathrm{~cm}$ were sandwiched between the two similar stainless steel electrodes of a spring-loaded sample holder. The whole assembly was placed in a furnace monitored by a temperature controller. The rate of heating was adjusted to be $2 \mathrm{~K} \cdot \mathrm{min}^{-1}$. Impedance measurements were performed on Gwinstek LCR-811OG in the frequency ranging from $20 \mathrm{~Hz}$ to $10 \mathrm{MHz}$ at different temperatures.

To form cathode pellet, a slurry obtained by mixing 0.9 gm $\left({ }_{0.6} \mathrm{TiO}_{2} /{ }_{0.4} \mathrm{rGO}\right)$ and $0.1 \mathrm{~g}$. PVA binder using magnetic stirrer hot plate $\left(60^{\circ} \mathrm{C}\right)$ for 2 hours is cast. The cathode is prepared by cold pressing 0.5 g. into a pellet of $13 \mathrm{~mm}$ diameter under 5 tons $/ \mathrm{cm}^{2}$. The electrolyte is deposited on the pellet substrate with APEX spin coater at $2000 \mathrm{rpm}$. The anode was prepared by cold pressing $0.6 \mathrm{~g}$. magnesium into a pellet of $13 \mathrm{~mm}$ in diameter under 5 tons $/ \mathrm{cm}^{2}$. Two-electrodes Swagelok test cell were assembled, Figure 1, the cell was discharged at room temperature on a multi-channel battery test system (NEWARE BTS-TC35) to analyze the electrochemical responses. The current density was $50 \mu \mathrm{A} / \mathrm{cm}^{2}$ for complete discharge curve, while $25 \mu \mathrm{A} / \mathrm{cm}^{2}$ for cycling.

\section{Results and Discussion}

Figure 2(a) and Figure 2(b) show the SEM images of the as-prepared $\mathrm{TiO}_{2}$ and ${ }_{0.6} \mathrm{TiO}_{2} / 0.4 \mathrm{rGO}$ composites. The SEM of $\mathrm{TiO}_{2}$ displays a surface with non-homogeneous porosity, Figure 2(a). However, $\left(0.6 \mathrm{TiO}_{2} /{ }_{0.4} \mathrm{rGO}\right)$ composites exhibit relatively compact surface with uniform distribution of $\mathrm{rGO}$ on $\mathrm{TiO}_{2}$, Figure 2(b).

Figure 3 shows XRD patterns of $\mathrm{rGO}, \mathrm{TiO}_{2}$ and $\left({ }_{0.6} \mathrm{TiO}_{2} /{ }_{0.4} \mathrm{rGO}\right)$ composites. The XRD pattern of rGO exhibits a broad weak diffraction peak at $2 \theta$ of $24.4^{\circ}(\mathrm{hkl}=002)$ [13], which is ascribed to disordered stacks of rGO nanosheets. The peaks of the $\left({ }_{0.6} \mathrm{TiO}_{2} / 0.4 \mathrm{rGO}\right)$ composites can be indexed to main anatase (JCPDS NO: 


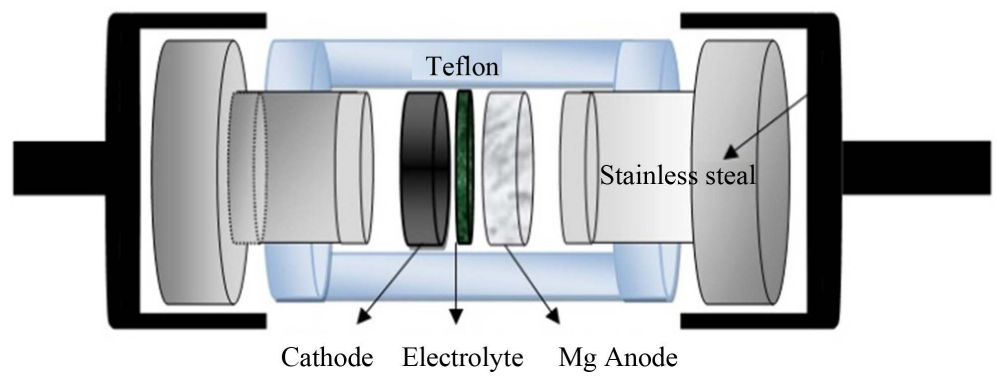

Figure 1. Schematic design of the lab cell.

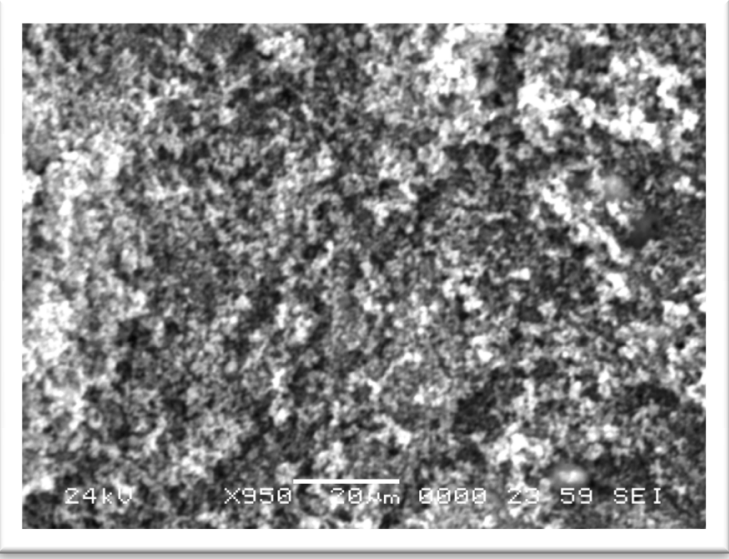

(a)

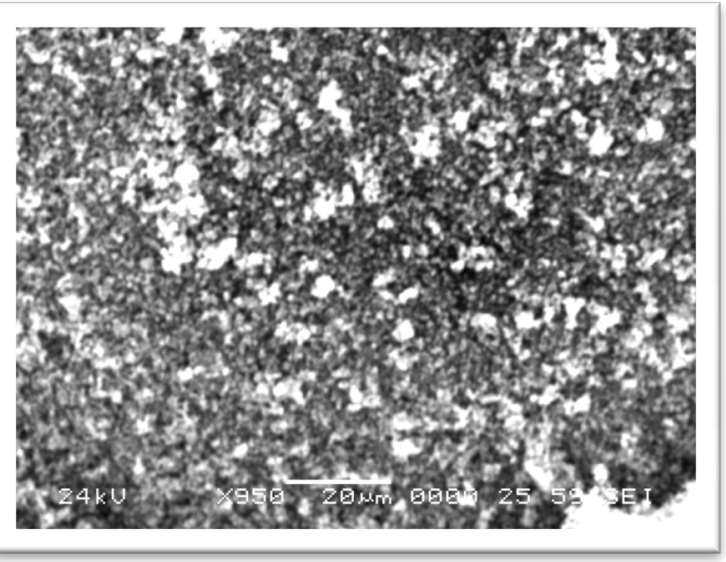

(b)

Figure 2. SEM micrographs of (a) $\mathrm{TiO}_{2}$; (b) $\left({ }_{0.6} \mathrm{TiO}_{2} / 0.4 \mathrm{rGO}\right)$.

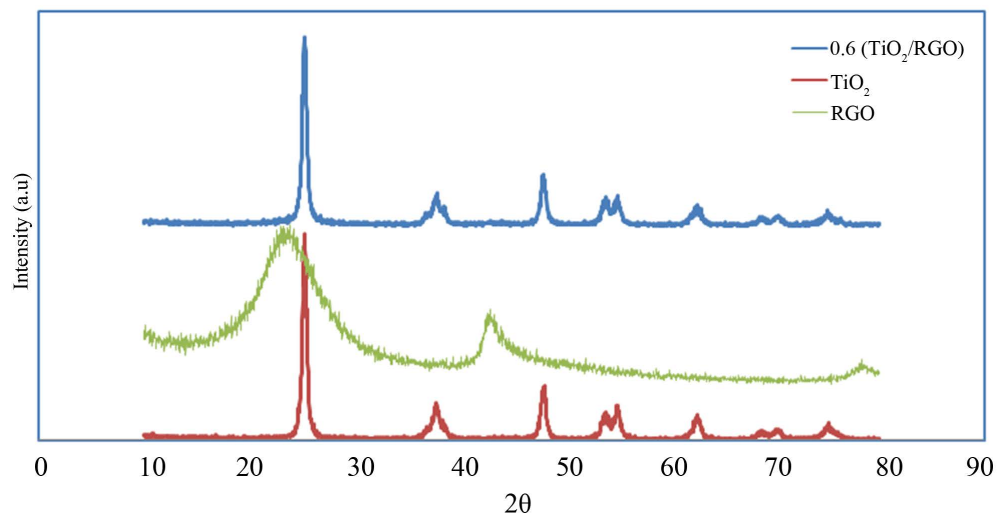

Figure 3. XRD pattern of $\mathrm{TiO}_{2},\left({ }_{0.6} \mathrm{TiO}_{2} / 0.4 \mathrm{rGO}\right)$ and $\mathrm{rGO}$.

01-089-4921) with a minor brookite phase (JCPDS NO: 003-0380). Additionally, it was observed that the $\left(0.6 \mathrm{TiO}_{2} /{ }_{0.4} \mathrm{rGO}\right)$ composite basically retains the position of the diffraction peaks of $\mathrm{TiO}_{2}$ but the intensity decreases in ${ }_{0.6} \mathrm{TiO}_{2} /{ }_{0.4} \mathrm{rGO}$ composite. This indicated that the incorporation of rGO considerably restrains the stacking of $\mathrm{TiO}_{2}$ layers. Furthermore, it can be hardly detected the (002) diffraction peaks of the rGO at $2 \theta=$ $24.4^{\circ}$ in the XRD patterns of the composite, which indicates that the rGO seldom stack during the ball mill process [11]. Furthermore, $\mathrm{TiO}_{2}$ and $\mathrm{rGO}$ interlace with each other to form a distinctive sandwich structure. The exfoliated $\mathrm{TiO}_{2}$ and rGO in the hybrids may provide more channels for reversible $\mathrm{Mg}^{2+}$ insertion-extraction than pristine $\mathrm{TiO}_{2}$.

The crystallite size (D) of $\mathrm{rGO} \mathrm{TiO}_{2}$ and $\left({ }_{0.6} \mathrm{TiO}_{2} / 0_{0.4} \mathrm{rGO}\right)$ composites was calculated from x-ray data using Scherrer equation as given below [14]: 


$$
\mathrm{D}=0.9 \lambda /(\mathrm{B} \cdot \cos \theta)
$$

where 0.9 is the Scherrer constant, $\lambda$ is the wavelength of $\mathrm{X}$-ray, $\mathrm{B}$ is the breadth of the pure diffraction profile and $\theta$ is the incidence angle of the $\mathrm{X}$-ray. Using this formula, the particle size of $\mathrm{TiO}_{2}$ and $\left(0_{0.6} \mathrm{TiO}_{2} / 0.4 \mathrm{rGO}\right)$ composites in the range 15 - $30 \mathrm{~nm}$ can be calculated as shown in Table 1.

Complex impedance plot of ${ }_{0.6} \mathrm{TiO}_{2} / 0.4 \mathrm{rGO}$ at different temperatures are shown in Figure 4(a) and Figure 4(b). The complex plot shows semicircle which correspond to the bulk resistance $R b$ with parallel combination of the

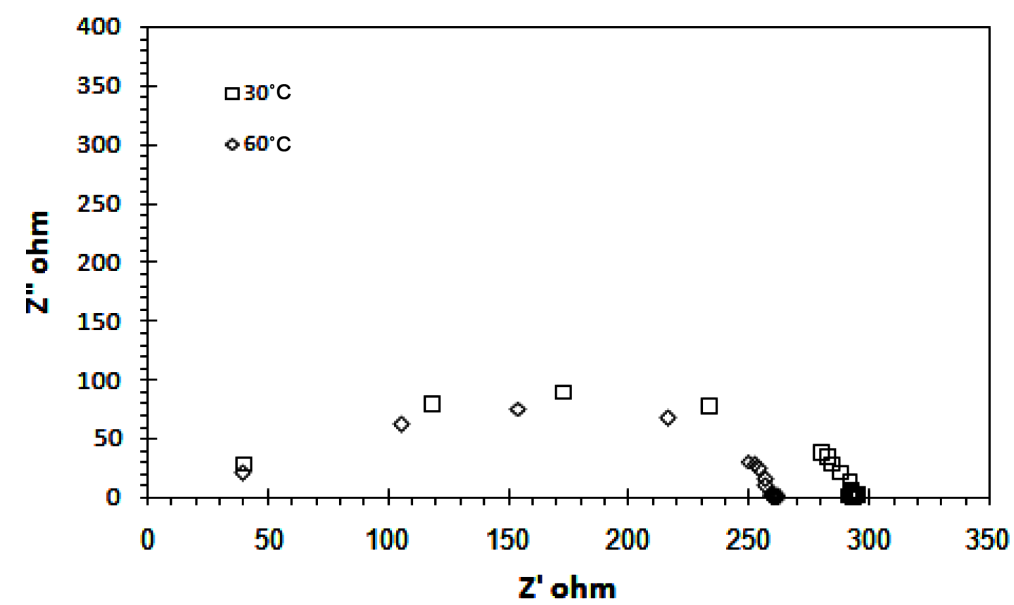

(a)

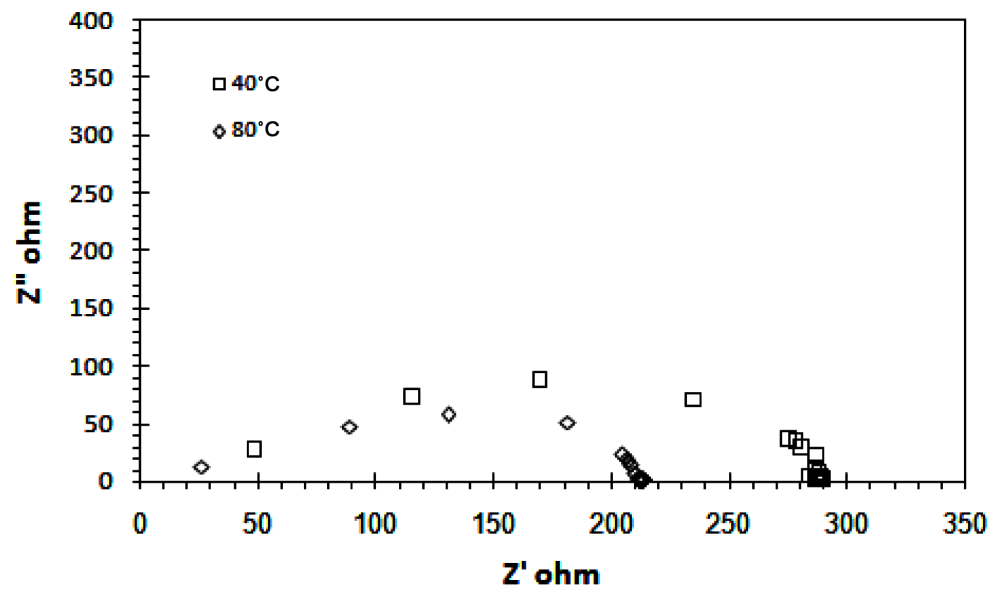

(b)

Figure 4. Cole Cole plots ${ }_{0.6} \mathrm{TiO}_{2} / 0.4 \mathrm{rGO}$ composites (a) $\mathrm{T}=30^{\circ} \mathrm{C}, 60^{\circ} \mathrm{C}$ and (b) $\mathrm{T}=40^{\circ} \mathrm{C}$ and $80^{\circ} \mathrm{C}$.

Table 1. XRD results of $\mathrm{TiO}_{2} / \mathrm{rGO}$ composites.

\begin{tabular}{cccccc}
\hline & $2 \theta$ & d spacing $(\mathrm{nm})$ & hkl & FWHM & Particle size $(\mathrm{nm})$ \\
\hline \multirow{2}{*}{ Graphene } & 24.94 & 3.29 & 002 & 0.84 & 9.68 \\
& 44.01 & 3.05 & - & 0.06 & 142.75 \\
$\mathrm{TiO}_{2}$ & 25.31 & 3.52 & 101 & 0.27 & 30.14 \\
& 37.80 & 2.38 & 004 & 0.24 & 34.97 \\
$\left(0.6 \mathrm{TiO}_{2} / 0.4 \mathrm{rGO}\right)$ & 25.30 & 3.52 & 101 & 0.27 & 30.14 \\
\hline
\end{tabular}


frequency dependent capacitance $C g$. The higher the temperature, the smaller the diameter of the semicircle. The bulk resistance value $R_{b}$ is determined from the low frequency intercepts on the x-axis of the complex impedance plots. The ionic conductivity is calculated using the equation $\sigma_{b}=\frac{1}{R_{b}} \times \frac{L}{A}$

where $L$ is the thickness of the polymer electrolyte film, $A$ is the surface area of the film.

The temperature dependence of bulk and ac conductivity of ${ }_{0.6} \mathrm{TiO}_{2} / 0_{0.4} \mathrm{rGO}$ composites is of the Arrhenius type:

$$
\sigma=\sigma_{o} \exp \left(\frac{-E_{a}}{K T}\right)
$$

where $\sigma_{o}$ in Equation (2) is a pre-exponential factor, $E_{a}$ the activation energy, $K$ is the Boltzmann constant and $T$ is the temperature in Kelvins. Figure 5 shows $\ln (\sigma)$ versus 1000/T plots at different constant frequencies. The $E_{\text {a }}$ values for two different thermal regions in the figure are presented in Table 2. It has been found that the values of activation energy is very small relative to the value of activation energy for pure $\mathrm{TiO}_{2}$. The values of activation energy decrease with the frequency. This can be attributed to the role of electrical signal frequencies to initiate the light charge $\left(\mathrm{e}^{-}\right)$.

Figure 6 shows the frequency dependence of the total conductivity for ${ }_{0.6} \mathrm{TiO}_{2} /{ }_{0.4} \mathrm{rGO}$ composites at different temperatures. It can be noticed that the behavior follows universal power law [15];

$$
\sigma_{a c}(\omega)=\sigma_{d c}+A \omega^{n}
$$

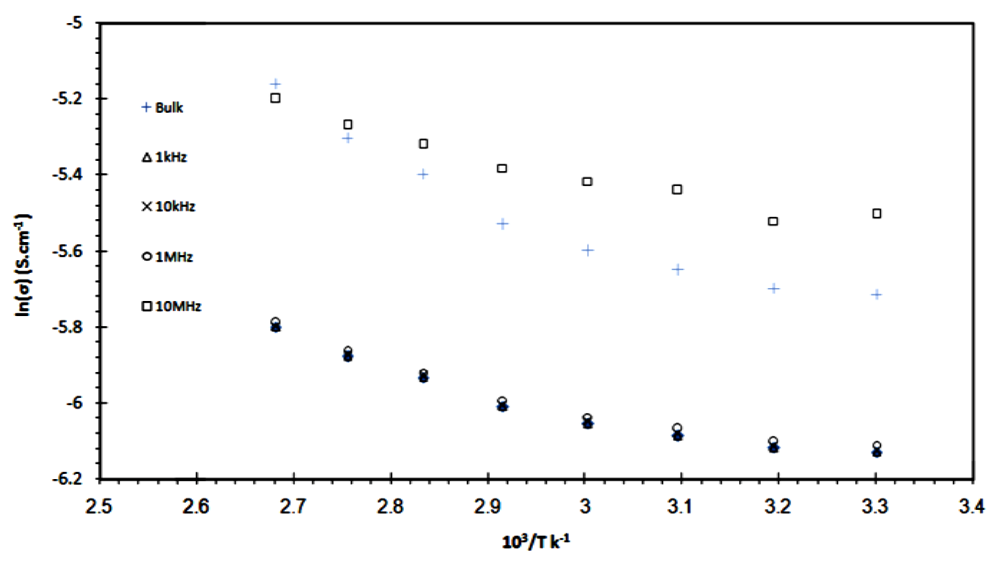

Figure 5. Temperature dependence of conductivity for ${ }_{0.6} \mathrm{TiO}_{2} / 0.4 \mathrm{rGO}$ at different constant frequencies.

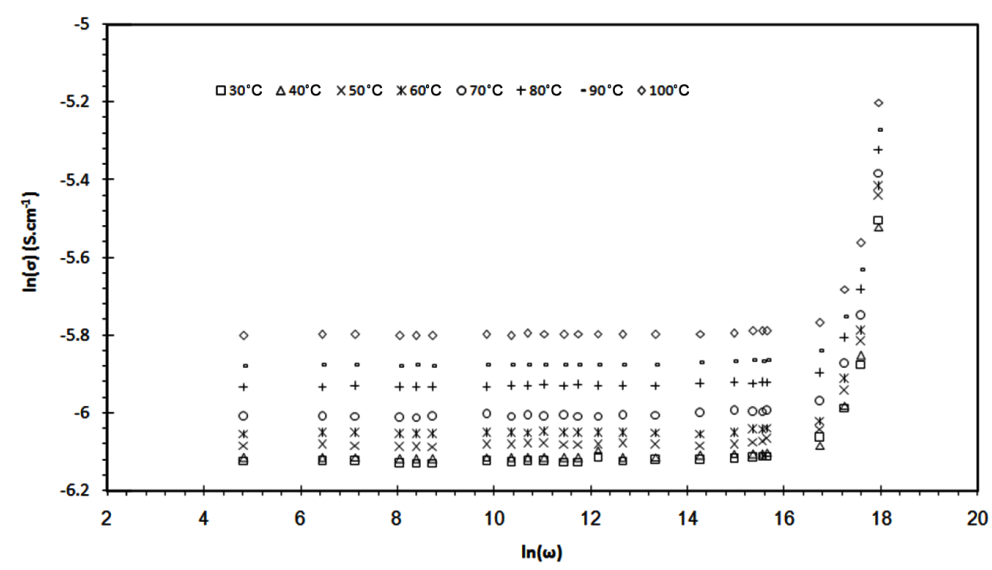

Figure 6. Frequency dependence of conductivity for ${ }_{0.6} \mathrm{TiO}_{2} /{ }_{0.4} \mathrm{rGO}$ at different constant temperatures. 
where $\sigma_{d c}$ is the dc conductivity (the extrapolation of the plateau region to zero frequency), $A$ is the frequency independent pre-exponential factor, $\omega$ is the angular frequency and $n$ is the frequency exponent. The values of the exponent $n$ have been obtained using the least square fitting of Equation (3) for two regions as listed in Table 2. It can be noticed that the values of $\mathrm{n}$ for the first region $n \sim 0$, frequency independent. The theoretical approaches of this behavior may be attributed to that the carriers transport takes place through infinite percolation path that can be explained by "percolation" model [16]. For the second region, relatively high frequencies, the values of $n$ lie within the range of $0.4<n<0.5$. The values of $n$, predict the domination of hopping conduction in ${ }_{0.6} \mathrm{TiO}_{2} / 0.4 \mathrm{rGO}$ composites.

Figure 7 shows the $I-V$ and $J-P$ characteristics for the $\mathrm{Mg} /\left(0_{0.6} \mathrm{TiO}_{2} / 0_{0.4} \mathrm{rGO}\right)$ battery at room temperature. The $I-V$ curve had a simple linear which indicates that the polarization on the electrode was primarily dominated by ohmic contributions [17]. The internal resistance of the battery was obtained from the gradient of the $I-V$ curve, which was $888 \Omega$. The plot of the operating $J-P$ suggests that the contact between electrolyte/electrodes was good. The voltage of the battery dropped to a short circuit current density of $0.13 \mathrm{~mA} \cdot \mathrm{cm}^{-2}$ and the maximum power density was determined to be $0.24 \mathrm{~mW} \cdot \mathrm{cm}^{-2}$.

Figure 8 shows the first discharge curve of the $\mathrm{Mg} /\left(0.6 \mathrm{TiO}_{2} /{ }_{0.4} \mathrm{rGO}\right)$ cell. The value of the discharge capacity $\mathrm{C}$ was evaluated from the equation [18]:

$$
C=\int_{0}^{t} I(t) \mathrm{d} t
$$

by integrating the area under curve of Figure 8 . The surface discharge capacity estimated by $2.2 \mathrm{mAh}$ for the limited electrode $\left(0.6 \mathrm{TiO}_{2} / 0_{0.4} \mathrm{rGO}\right)$. Figure 9(a) and Figure 9(b) show the voltage profiles during charge/discharge cycling at constant time and constant current. The operating voltage ranges from 0.5 to $4 \mathrm{~V}$, and the capacity of the battery quickly stabilizes within the first several cycles. The shape of charge and discharge curves were relatively constant with cycling (50 cycles), which show that this kind of cell may be promising in reversible intercalation and de-intercalation of $\mathrm{Mg}$ ions. Therefore, the charge-discharge reaction mechanism of $\mathrm{Mg} /\left({ }_{0.6} \mathrm{TiO}_{2} /{ }_{0.4} \mathrm{rGO}\right)$ cell can be formulated as the following equations:

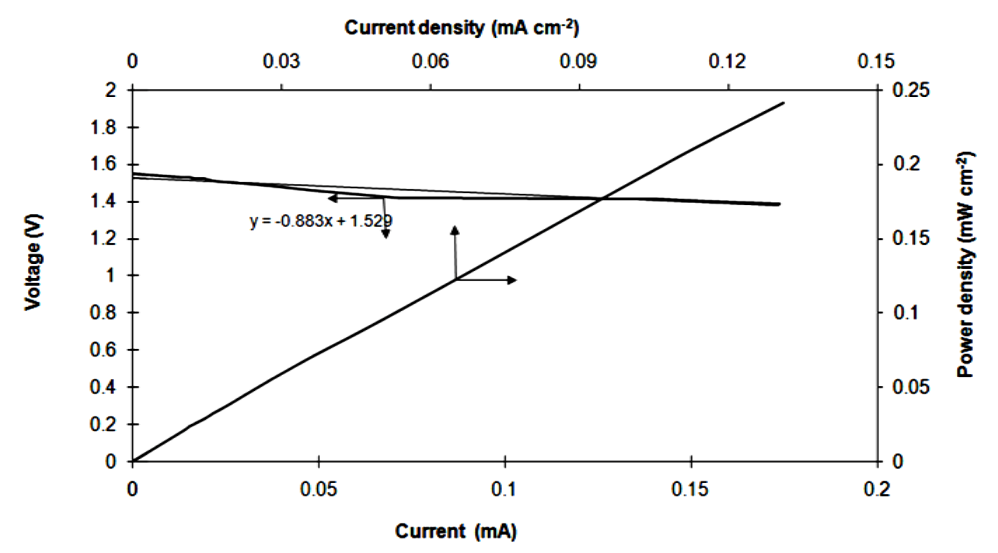

Figure 7. I-V and J-P curves for $\mathrm{Mg} / \mathrm{PE} /\left(0.6 \mathrm{TiO}_{2} / 0.4 \mathrm{TGO}\right)$ cell.

Table 2. Electrical parameters of ${ }_{0.6} \mathrm{TiO}_{2} / 0.4 \mathrm{rGO}$ composites.

\begin{tabular}{ccccccc}
\hline $\mathbf{F ~ ( H z )}$ & $\mathbf{E}_{\mathbf{1}}(\mathbf{e V})$ & $\mathbf{E}_{\mathbf{2}}(\mathbf{e V})$ & $\mathbf{T e m p}^{\circ} \mathbf{C}$ & $\boldsymbol{n}_{\mathbf{1}}$ & $\boldsymbol{n}_{\mathbf{2}}$ \\
\hline 0 & 0.034 & 0.132 & 30 & 0.0012 & 0.437 \\
$10^{3}$ & 0.022 & 0.075 & 50 & 0.001 & 0.472 \\
$10^{4}$ & 0.022 & 0.076 & 60 & 0.001 & 0.474 \\
$10^{5}$ & 0.021 & 0.074 & 80 & 0.0011 & 0.454 \\
$10^{6}$ & 0.021 & 0.073 & 90 & 0.0012 & 0.447 \\
$10^{7}$ & 0.029 & 0.065 & 100 & 0.0009 & 0.444 \\
\hline
\end{tabular}




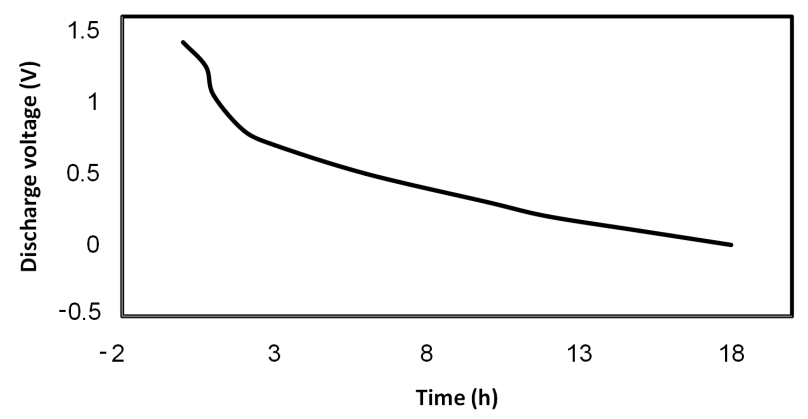

Figure 8. First discharge curve of $\mathrm{Mg} / \mathrm{PE} /\left({ }_{0.6} \mathrm{TiO}_{2} /{ }_{0.4} \mathrm{rGO}\right)$ cell.

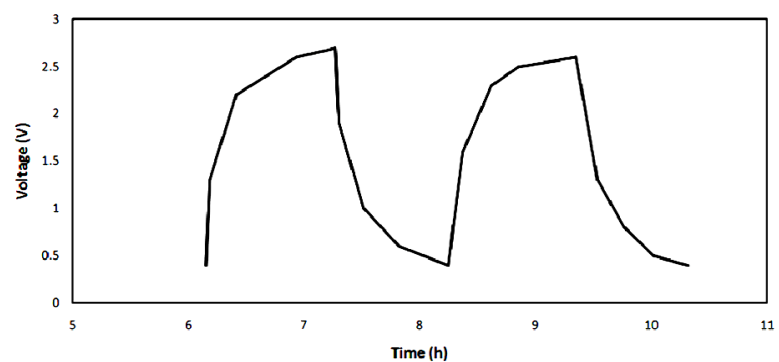

(a)

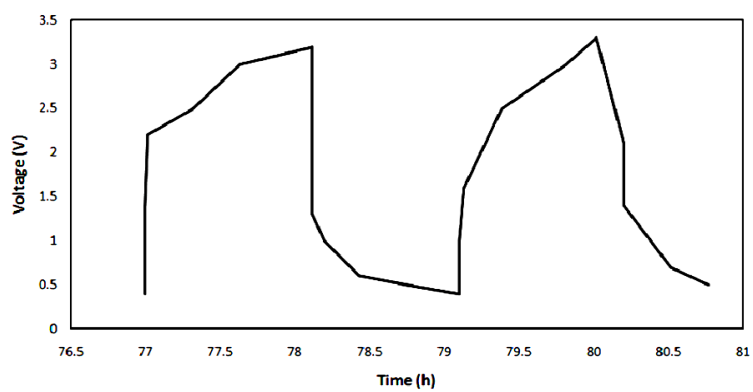

(b)

Figure 9. Charge-discharge cycles of $\mathrm{Mg} / \mathrm{PE} /\left({ }_{0.6} \mathrm{TiO}_{2} /{ }_{0.4} \mathrm{rGO}\right)$ cell (a) Cycle 3 and 4; (b) Cycle 35 and 36.

$$
\mathrm{TiO}_{2}+{ }_{x} \mathrm{Mg}^{+2}+_{x} \mathrm{e}^{-} \leftrightarrow \mathrm{Mg}_{x} \mathrm{TiO}_{2}
$$

\section{Conclusions}

From the above findings it can be concluded that:

${ }_{0.6} \mathrm{TiO}_{2} /{ }_{0.4} \mathrm{rGO}$ composites were synthesized by a ball mill method. SEM and x-ray analyses confirmed that reduced graphene oxide is well distributed on $\mathrm{TiO}_{2}$. These composites exhibited a reversible magnesium storage capacity and accepted cycling performance when applied as a cathode material in Mg-ion batteries. Hence, ${ }_{0.6} \mathrm{TiO}_{2} /{ }_{0.4} \mathrm{rGO}$ is a promising cathode material for magnesium ion batteries with a promising cycling performance due to its low volume expansion upon cycling.

\section{Acknowledgements}

We are grateful to the Science technology development fund of Egypt, grant number 4758.

\section{References}

[1] Park, J., Kim, J., Park, J.-W., Nam, J., Kim, K., Ahn, J., Wang, G.X. and Ahn, H.-J. (2013) Discharge Mechanism of 
$\mathrm{MoS}_{2}$ for Sodium Ion Battery: Electrochemical Measurements and Characterization. Electrochimica Acta, 92, 427-432. http://dx.doi.org/10.1016/j.electacta.2013.01.057

[2] Lv, D.P., Xu, T., Sahaa, P., Dattaa, M.K., Gordin, M.L., Manivannan, A., Kumta, P.N. and Wang, D.H. (2013) A Scientific Study of Current Collectors for Mg Batteries in $\mathrm{Mg}\left(\mathrm{AlCl}_{2} \mathrm{EtBu}\right)_{2} / \mathrm{THF}$ Electrolyte. Journal of the Electrochemical Society, 160, A351-A355.

[3] Peng, B., Liang, J., Tao, Z. and Chen, J. (2009) Magnesium Nanostructures for Energy Storage and Conversion. Journal of Materials Chemistry, 19, 2877-2883. http://dx.doi.org/10.1039/b816478a

[4] Li, W.Y., Li, C.S., Zhou, C.Y., Ma, H. and Chen, J. (2006) Metallic Magnesium Nano/Mesoscale Structures: Their Shape-Controlled Preparation and Mg/Air Battery Applications. Angewandte Chemie International Edition, 45, 60096012. http://dx.doi.org/10.1002/anie.200600099

[5] Liu, Y., Jiao, L., Wu, Q., Du, J., Zhao, Y., Si, Y., Wang, Y.J. and Yuan, H.T. (2013) Sandwich-Structured GrapheneLike MoS2/C Microspheres for Rechargeable Mg Batteries. Journal of Materials Chemistry A, 1, 5822-5826. http://dx.doi.org/10.1039/c3ta10786h

[6] Aurbach, D., Lu, Z., Schechter, A., Gofer, Y., Gizbar, H., Turgeman, R., Cohen, Y., Moshkovich, M. and Levi, E. (2000) Prototype Systems for Rechargeable Magnesium Batteries. Nature, 407, 724-727. http://dx.doi.org/10.1038/35037553

[7] Abdel-Samiea, B.M., Basyouni, A., Khalil, R.M., Sheha, E., Tsuda, H. and Matsui, T. (2013) The Role of TiO ${ }_{2}$ Anatase Nano-Filler to Enhance the Physical and Electrochemical Properties of PVA-Based Polymer Electrolyte for Magnesium Battery. Journal of Materials Science and Engineering A, 3, 678-689

[8] Sheha, E. (2013) Prototype System for Magnesium/TiO ${ }_{2}$ Anatase Batteries. International Journal of Electrochemical Science, 83, 653.

[9] Hou, J., Wu, R., Zhao, P., Chang, A., Ji, G., Gao, B., Gao, B. and Zhao, Q. (2013) Graphene-TiO 2 (B) Nanowires Composite Material: Synthesis, Characterization and Application in Lithium-Ion Batteries. Materials Letters, 100, 173176. http://dx.doi.org/10.1016/j.matlet.2013.03.004

[10] Li, J., Wan, W., Zhou, H., Li, J. and Xu, D. (2011) Hydrothermal Synthesis of $\mathrm{TiO}_{2}(\mathrm{~B})$ Nanowires with Ultrahigh Surface Area and Their Fast Charging and Discharging Properties in Li-Ion Batteries. Chemical Communications, 47, 3439-3441. http://dx.doi.org/10.1039/c0cc04634e

[11] Armstrong, A.R., Armstrong, G., Canales, J. and Bruce, P.G. (2004) Lithium-Ion Intercalation into TiO ${ }_{2}$-B Nanowires. Angewandte Chemie International Edition, 43, 2286-2288. http://dx.doi.org/10.1002/anie.200353571

[12] Zhao, H., Pan, L., Xing, S., Luo, J. and Xu, J. (2013) Vanadium Oxides-Reduced Graphene Oxide Composite for Lithium-Ion Batteries and Supercapacitors with Improved Electrochemical Performance. Journal of Power Sources, 222, 21-31. http://dx.doi.org/10.1016/j.jpowsour.2012.08.036

[13] Liu, Y., Jiao, L., Wu, Q., Zhao, Y., Cao, K., Liu, H., Wang, Y. and Yuan, H. (2013) Synthesis of rGO-Supported Layered $\mathrm{MoS}_{2}$ for High-Performance Rechargeable Mg Batteries. Nanoscale, 5, 9562-9567.

[14] Kitazawa, S., Choi, Y., Yamamoto, S. and Yamaki, T. (2006) Rutile and Anatase Mixed Crystal TiO 2 Thin Films Prepared by Pulsed Laser Deposition. Thin Solid Films, 515, 1901-1904. http://dx.doi.org/10.1016/j.tsf.2006.07.032

[15] Jonscher, A.K. (1977) The “Universal” Dielectric Response. Nature, 267, 673-679. http://dx.doi.org/10.1038/267673a0

[16] Karlsson, L. and Mcgreevy, R.L. (1995) Mechanisms of Ionic Conduction in $\mathrm{Li}_{2} \mathrm{SO}_{4}$ and $\mathrm{LiNaSO}_{4}$ : Paddle Wheel or Percolation. Solid State Ionics, 76, 301-308. http://dx.doi.org/10.1016/0167-2738(94)00278-Z

[17] Ng, L.S. and Mohamad, A.A. (2006) Protonic Battery Based on a Plasticized Chitosan- $\mathrm{NH}_{4} \mathrm{NO}_{3}$ Solid Polymer Electrolyte. Journal of Power Sources, 163, 382-385. http://dx.doi.org/10.1016/j.jpowsour.2006.09.042

[18] Sheha, E. (2009) Ionic Conductivity and Dielectric Properties of Plasticized $\mathrm{PVA}_{0.7}\left(\mathrm{LiBr}_{0.3}\left(\mathrm{H}_{2} \mathrm{SO}_{4}\right)_{2.7 \mathrm{M}}\right.$ Solid Acid Membrane and Its Performance in a Magnesium Battery. Solid State Ionics, 180, 1575-1579.

http://dx.doi.org/10.1016/j.ssi.2009.10.008 
Scientific Research Publishing (SCIRP) is one of the largest Open Access journal publishers. It is currently publishing more than 200 open access, online, peer-reviewed journals covering a wide range of academic disciplines. SCIRP serves the worldwide academic communities and contributes to the progress and application of science with its publication.

Other selected journals from SCIRP are listed as below. Submit your manuscript to us via either submit@scirp.org or Online Submission Portal.
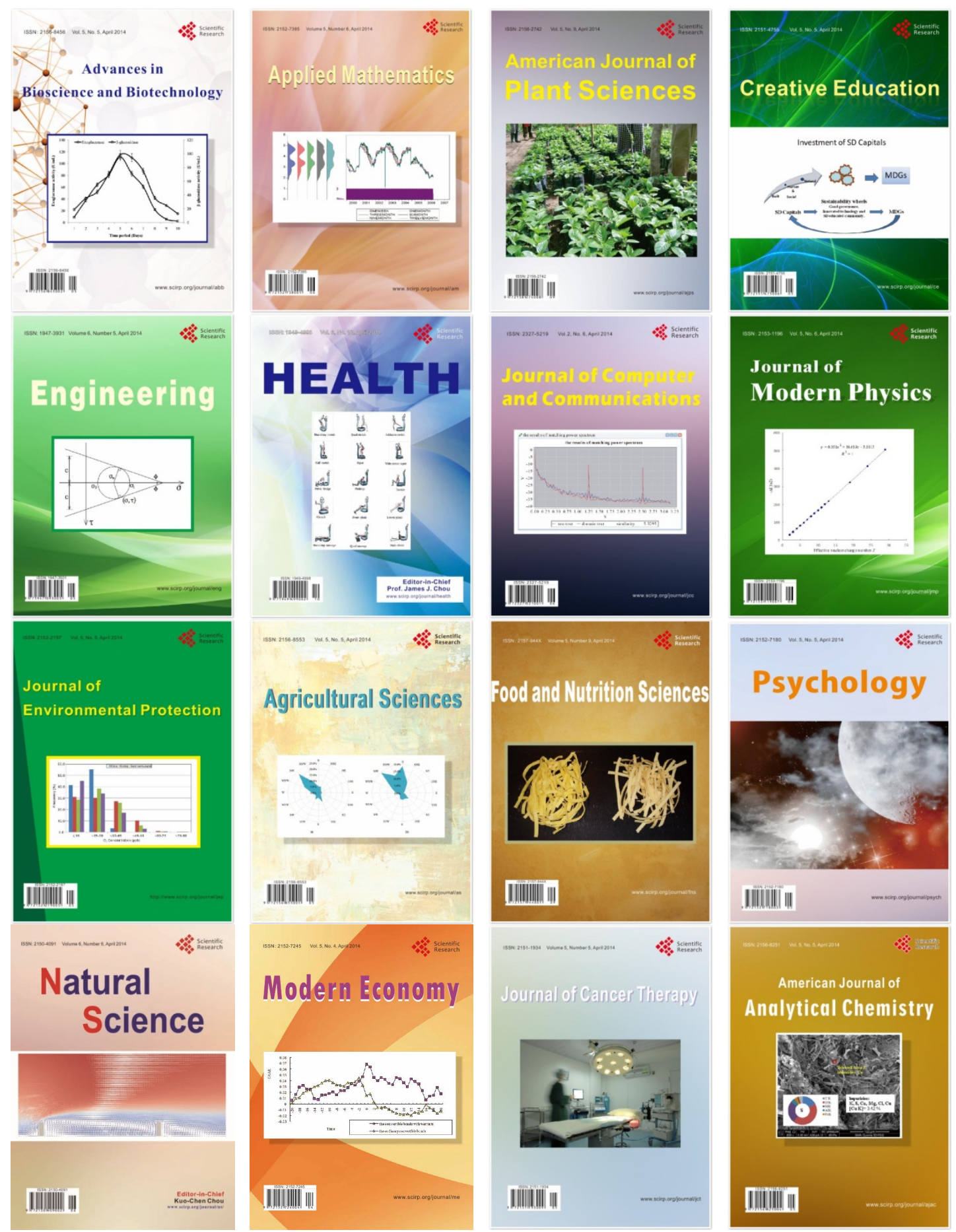